\title{
Peringkasan Tweet Berdasarkan Trending Topic Twitter Dengan Pembobotan TF-IDF dan Single Linkage Angglomerative Hierarchical Clustering
}

\author{
Annisa ${ }^{1}$, Yuda Munarko², Yufis Azhar ${ }^{3}$ \\ $1,2,3$ Universitas Muhammadiyah Malang \\ annisakawaii@ymail.com¹, yuda@umm.ac.id², yufis@umm.ac.id ${ }^{3}$
}

\begin{abstract}
Abstrak
Fitur yang paling sering digunakan pada Twitter ialah Trending Topic. Trending Topic merupakan fitur yang menampilkan beberapa hashtag berisi topik yang sedang trend saat ini. Jika pengguna ingin mengetahui informasi mengenai suatu trending topic, pengguna bisa mengklik salah satu hashtag dan barulah muncul beberapa tweet terkait dengan hashtag tersebut. Agar menghemat waktu pengguna Twitter dalam membaca suatu trending topic tanpa perlu membaca beberapa tweet terlebih dahulu, maka dilakukanlah analisa dengan tujuan membuat text summarization untuk trending topic pada Twitter menggunakan algoritma TF-IDF dan Single Linkage Agglomerative Hierarchical Clustering. Penelitian ini menggunakan 100 trending topic untuk data tes pada sistem dan setiap trending topic terdiri atas 50 tweet berbahasa indonesia, sedangkan untuk pengujian digunakan 30 data trending topic diambil secara acak (data mewakili trending topic dengan sub tema minimal 2 dan maksimal 9 dari 100 data tes pada sistem). Dari 30 data pengujian, 1 data menghasilkan semua ringkasan sama persis dengan ahli, dan 29 data menghasilkan 1-4 ringkasan sama persis dengan ahli (terdiri atas 2-9 ringkasan untuk setiap trending topic).
\end{abstract}

Kata kunci:Text Summarization, TF-IDF, Single Linkage Agglomerative Hierarchical Clustering

\begin{abstract}
Trending topic is a feature provided by twitter that informs something widely discussed by users in a particular time. The form of trending topic is a hash tag and can be selected by clicking. However, the number of tweets for each trending topics can be very large, so it will be difficult if we want to know all the contents. So, in order to make easy when reading the topic, a small number of tweets can be selected as the main idea of the topic. In this study, we applied the Agglomerative Single Linkage Hierarchical Clustering by calculating the TF-IDF value for each words in advance. We used 100 trending topics, where each topics consists of 50 tweets in Indonesian. For testing, we provided 30 trending topics which consist of 2 until 9 sub topics. The result is that each trending topics can be summarized into shorter text contains 2 until 9 tweets. We were able to summarized 1 trending topics exactly same as the topic summarized by human expert. However, the rest of topics corresponded partially with human expert.
\end{abstract}

Keywords: Text Summarization, TF-IDF, Single Linkage Agglomerative Hierarchical Clustering

\section{Pendahuluan}

Salah satu faktor penting penunjang globalisasi ialah internet. Semakin majunya teknologi internet menyebabkan banyaknya pengembang perangkat lunak membuat berbagai macam aplikasi online, salah satunya yakni sosial media. Banyak sosial media yang saat ini sedang digandrungi, baik itu dari luar negeri maupun dalam negeri. Salah satu contoh sosial media yang sedang trend saat ini, yakni Twitter.

Pada jejaring sosial Twitter terdapat berbagai macam fitur, salah satu fitur yang paling sering digunakan ialah Trending Topic. Trending Topic merupakan fitur yang menampilkan beberapa hashtag yang berisi topik yang sedang trend saat ini di Twitter. Jika pengguna ingin mengetahui informasi atau berita mengenai salah satu trending topic tadi, pengguna bisa 
mengklik salah satu hashtag dan barulah muncul beberapa tweet terkait dengan hashtag tersebut.

Hal tersebut tentulah merepotkan pengguna dan membuang waktu jika harus membaca beberapa tweet terlebih dahulu hanya untuk mengetahui informasi atau berita yang akurat pada suatu trending topic. Kalaupun hanya membaca tweet teratas atau terbaru mengenai trending topic tadi, belum tentu tweet tersebut mewakili berita atau informasi yang ingin disampaikan, karena biasanya beberapa tweet ada yang melenceng dari hashtag atau tema.

Berdasarkan permasalahan di atas mengenai fitur trending topic, untuk memudahkan dan menghemat waktu pengguna Twitter dalam mengetahui sebuah informasi atau berita pada salah satu trending topic tanpa perlu membaca beberapa tweet terlebih dahulu, maka dilakukanlah analisa untuk membuat ringkasan otomatis (text summarization) untuk mult itweet berdasarkan trending topic Twitter. Text summarization ialah suatu proses yang secara otomatis menghasilkan informasi berupa ringkasan yang berguna untuk user [1].

Berdasarkan literatur "Pembangunan Perangkat Lunak Peringkas Dokumen Dari Banyak Sumber Menggunakan Sentence Scoring Dengan Metode TF-IDF", bahwa untuk mengoptimalkan pemilihan kalimat yang digunakan sebagai ringkasan, akan lebih baik jika digabungkan dengan metode yang mencari kemiripan antar kata atau kalimat sehingga mengatasi resiko apabila terdapat kemiripan [2].

Biasanya dalam sebuah trending topic ada beberapa tweet yang melenceng dari hashtag, contohnya 5 data tweet dalam trending topic "PHK" pada Tabel 1 , sebagai berikut:

Tabel 1. Trending Topic PHK

\begin{tabular}{cl}
\hline Data & \multicolumn{1}{c}{ Tweet } \\
\hline T1 & PHK Pekerja Toshiba \\
T2 & Pekerja Toshiba kena PHK \\
T3 & Jual Sony Xperia Z5 http://www.jualhp.sony/xperia/z5 \\
T4 & RT Pekerja Toshiba kena PHK \\
T5 & Jual Sony Xperia Z5 http://www.jualhp.sony/xperia/z5 \\
\hline
\end{tabular}

Berdasarkan Tabel 1 dapat lihat T1, T2, dan T4 membicarakan tentang PHK, sedangkan T3 dan T5 membicarakan tentang menjual hp. Oleh sebab itu, untuk mengatasi adanya sub topik yang muncul lebih dari satu dalam suatu trending topic, maka sebelum dilakukan peringkasan perlu klasterisasi data tweet terlebih dahulu.

Clustering adalah suatu teknik pengelompokkan data ke dalam objek yang serupa [3]. Ada dua metode clustering yang kita kenal, yaitu hierarchical clustering dan partitioning. Pada penelitian ini digunakan metode hierarchical clustering karena tidak memerlukan input berapa jumlah cluster data, sebab pada sebuah trending topic tidak diketahui berapa jumlah tweet yang akan melenceng dari hashtag.

Penelitian ini bertujuan untuk membuat sebuah sistem yang dapat menghasilkan ringkasan secara otomatis yang sesuai dengan multi tweet berdasarkan trending topic dengan menggunakan algoritma TF-IDF dan Single Linkage Agglomerative Hierarchical Clustering.

Batasan masalah untuk penelitian ini, yaitu tweet berbahasa Indonesia, setiap trending topic mengambil sample 50 tweet untuk dilakukan peringkasan, dan data test untuk sistem terdiri atas 100 trending topic yang dikumpulkan mulai tanggal 2 Februari 2016 - 13 Maret 2016.

Perbedaan antara penelitian ini dengan penelitian sebelumnya "Pembangunan Perangkat Lunak Peringkas Dokumen Dari Banyak Sumber Menggunakan Sentence Scoring Dengan Metode TF-IDF" adalah penelitian sebelumnya membangun sistem text summarization untuk dokumen dari banyak sumber dan tidak ada tahapan clustering didalam sistemnya sedangkan pada penelitian ini membangun sistem text summarization untuk multi tweet dan terdapat tahapan clustering sebelum dilakukan peringkasan tweet.

\section{Metode Penelitian}

Metode text summarization yang digunakan pada penelitian ini ialah metode extractive summary. Teknik ini meringkas dengan cara menyalin unit-unit teks yang dianggap paling penting dan dapat mewakili teks sumber menjadi ringkasan.

Tahapan pada sistem text summarization untuk trending topic pada Twitter dalam bahasa Indonesia terdiri atas 4 tahapan, sebagai berikut: 
1. Tahapan pertama mengumpulkan data tweet melalui web crawler dengan memanfaatkan API Twitter. Setelah dokumen tersimpan dilakukan preprocessing yang terdiri atas 7 tahapan, sebagai berikut:

a. Pemecahan tweet yaitu proses memecah string teks dokumen yang panjang menjadi kumpulan tweet. Dalam memecah dokumen menjadi beberapa tweet menggunakan fungsi split( ),dengan tanda baris baru sebagai delimiter untuk memotong string dokumen.

b. Case folding ialah tahapan mengubah semua huruf pada tweet menjadi huruf kecil, menghilangkan karakter angka, dan menghilangkan delimiter seperti ( . ), ( , ), (:), ( ; ), ( ?), dan (!).

c. Tokenizing ialah tahapan penguraian deskripsi dari tweet menjadi kata-kata dengan pemisah spasi.

d. Editing ialah tahapan mengubah kata-kata yang disingkat menjadi kata aslinya dan mengubah kata tidak baku menjadi kata baku.

e. Tahapan untuk menghilangkan kata-kata yang dianggap tidak penting (stopwords), seperti kata di, ke, apa, dan, ini, itu, pun, agar, akan, dari, juga, oleh, pada, yang, bahwa, dapat, namun, untuk, dengan, kepada, ya, nya.

f. Normalisasi ialah tahapan menghilangkan tag-tag yang tidak penting biasanya muncul pada tweet, seperti link diawali dengan http, mentioned diawali dengan simbol @, hashtag diawali dengan simbol \#, dan retweet yg dilambangkan dengan RT diawal tweet. g. Stemming ialah tahapan pemetaan dari bentuk (variants) menjadi kata dasar.

Pada penelitian ini tahapan editing, normalisasi, dan stemming dilakukan secara manual.

2. Tahapan kedua yaitu perhitung bobot kata dengan TF-IDF. TF(Term Frequency) ialah frekuensi banyaknya kata yang muncul pada sebuah dokumen, sedangkan IDF ialah kemunculan term atau kata pada kumpulan dokumen. Persamaan IDF adalah sebagai berikut.

$$
I D F(t)=\log \frac{N}{d f(t)}
$$

Dimana $d f(t)$ adalah banyak dokumen yang mengandung term $t$. TF* IDF merupakan kombinasi metode TF dengan metode IDF. Sehingga persamaan TF*IDF adalah sebagai berikut:

$$
T F-I D F(d, t)=T F(d, t) * I D F(t)
$$

3. Tahapan ketiga yaitu klasterisasi data dari hasil perhitungan bobot TF-IDF menggunakan metode Single Linkage Agglomerative Hierarchical Clustering.

Cara kerja algoritma Single Linkage Agglomerative Hierarchical Clustering menggunakan prinsip jarak minimum yang diawali dengan mencari dua objek terdekat dan keduanya membentuk cluster yang pertama. Pada langkah selanjutnya terdapat dua kemungkinan, yaitu :

a. Objek ketiga akan bergabung dengan cluster yang telah terbentuk, atau

b. Dua objek lainnya akan membentuk cluster baru.

Proses ini akan berlanjut sampai akhirnya terbentuk cluster tunggal. Data yang digunakan untuk menghitung cluster ialah Euclidean Matrix yang didapatkan berdasarkan persamaan berikut:

$$
\text { EuclideanDis } \tan c e(X, Y)=\sqrt{\sum(X i-Y i)^{2}}
$$

Pada penelitian ini tahap penggabungan cluster (memilih level cluster terbaik), menggunakan ukuran dissimilarity antar cluster dengan UPGMA (Unweighted Pair Group Method Average) [4,5], ditunjukkan pada Persamaan 4. 


$$
\operatorname{Dissimilarity}(\text { cluster } 1, \text { cluster } 2)=\frac{\sum \text { Euclidean }(d 1, d 2)}{\text { sizecluster } 1 * \text { sizecluster } 2}
$$

Teknik UPGMA pada penelitian ini dilihat dari ketidak miripan semua dokumen dari cluster, untuk nilai tengah cluster yang didefinisikan dengan Persamaan 5

$$
\operatorname{Sim}(X)=\sum_{d e x} \text { Euclidean }(d, c)
$$

dimana $d$ ialah dokumen pada cluster $X$, dan $c$ ialah nilai tengah dari cluster $X$ yang merupakan mean (nilai tengah) dari vector dokumen. Pemilihan untuk penggabungan cluster terbaik (memilih level cluster yang tepat) berdasarkan nilai terbesar dari Persamaan 6 .

4. Tahapan keempat menentukan ringkasan untuk setiap cluster. Jika jumlah anggota cluster 1 , maka anggota tersebut yang menjadi ringkasan. Sedangkan saat jumlah anggota cluster lebih dari 1, maka yang menjadi ringkasan ialah salah satu anggota cluster dengan nilai keterkaitan antar tweetter kecil dengan persamaan nilai sebagai berikut:

$$
\text { nilai }=\frac{\sum \text { EuclideanDis } \tan c e}{n}
$$

Jumlah kesimpulan yang muncul sama dengan jumlah cluster atau sub topik yang ada pada sebuah trending topic.

Berikut contoh gambaran sistem untuk peringkasan trending topic tentang "tes" pada Gambar 1:

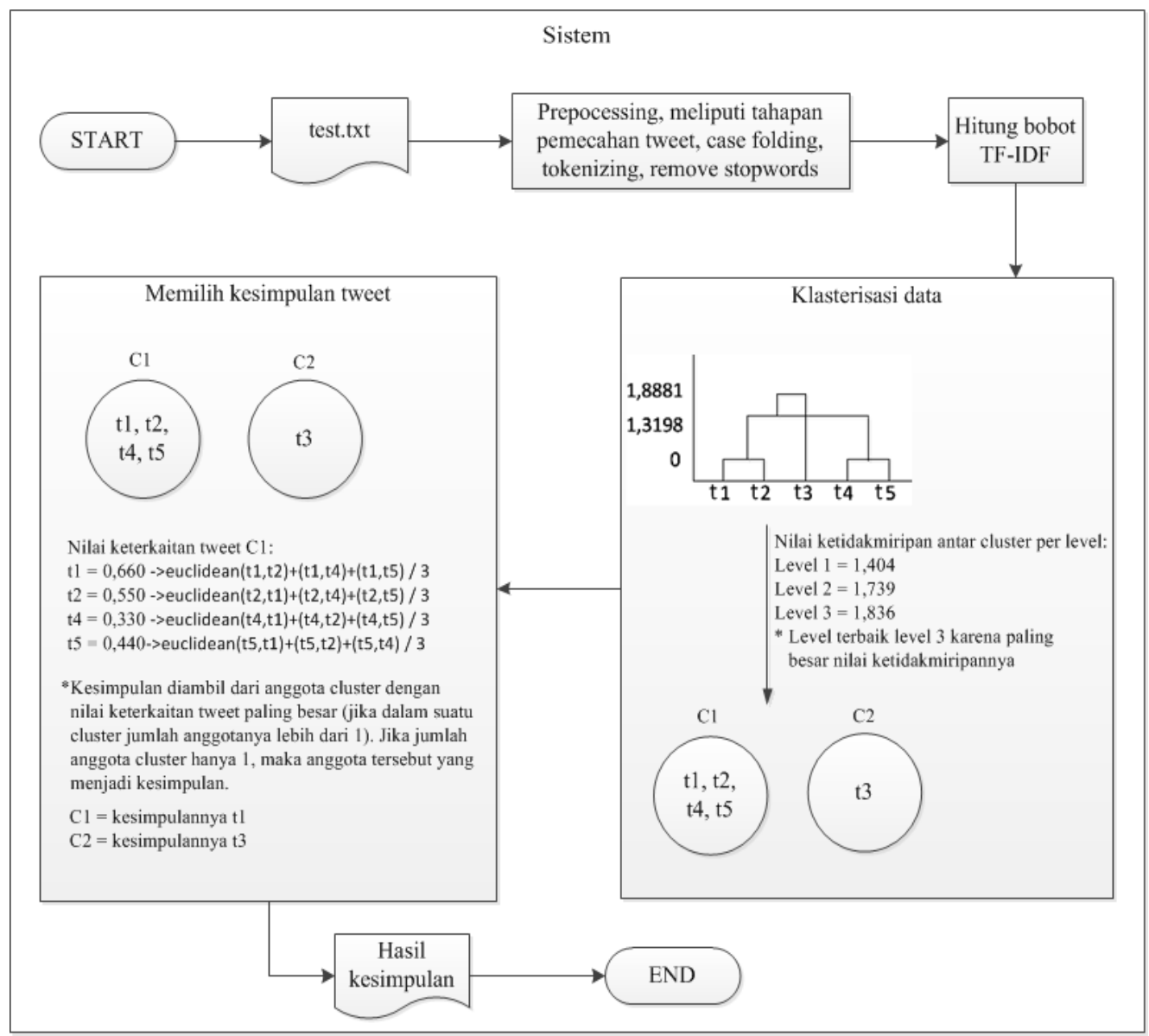

Gambar 1. Gambaran Sistem 


\section{Hasil Penelitian dan Pembahasan}

Berikut tampilan antarmuka halaman hasil ringkasan dari sistem text summarization untuk trending topic pada Twitter dalam bahasa Indonesia:

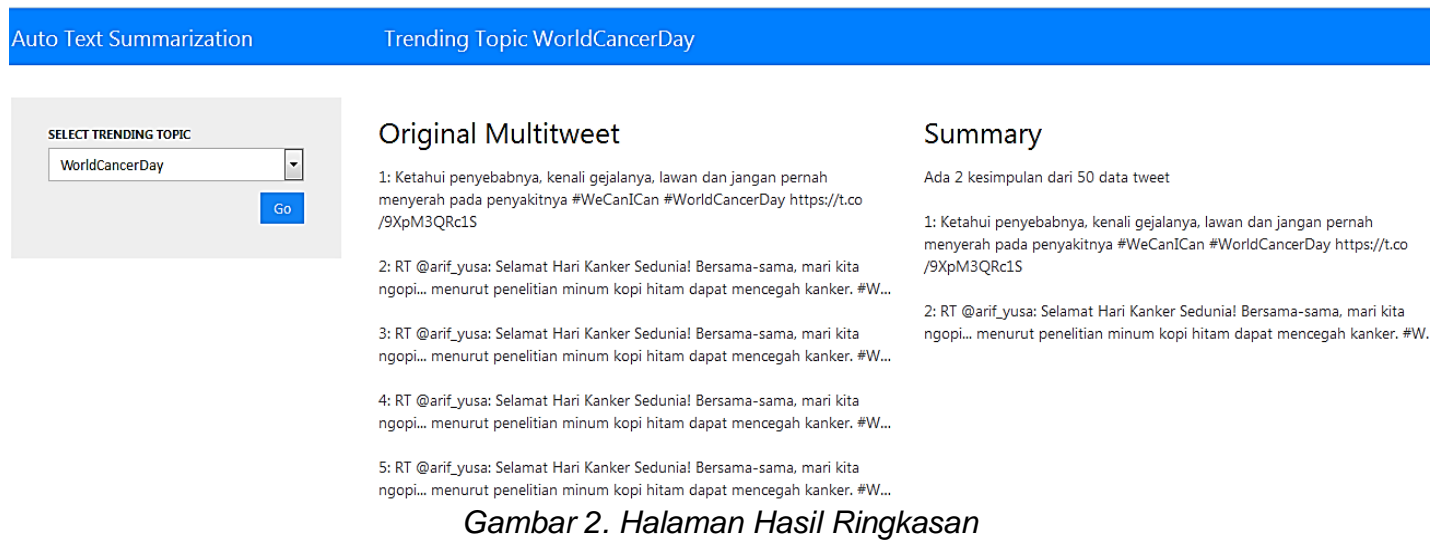

Pengujian terhadap sistem text summarization untuk trending topic pada Twitter dalam bahasa Indonesia ini ada dua, yaitu pengujian terhadap cluster dan pengujian terhadap hasil ringkasan tweet.

Data yang digunakan untuk pengujian adalah 30 data trending topic diambil secara acak (data mewakili trending topic dengan sub tema minimal 2 dan maksimal 9 dari 100 data tes pada sistem).

Pertama, pengujian cluster dengan F-Measure, merupakan metode pengujian yang menghubungkan antara nilai precision dan recall, dirumuskan sebagai berikut:

$$
F-\text { Measure }=\frac{2 x \text { precision } \times \text { recall }}{\text { precision }+ \text { recall }}
$$

Skenario pengujian cluster pada penelitian ini adalah dengan membandingkan hasil cluster yang dibuat secara manual oleh ahli dengan hasil cluster dari sistem. Jumlah cluster telah ditentukan terlebih dahulu sesuai dengan keluaran dari sistem. Saat nilai F-Measure mendekati atau mencapai 100\%, maka semakin mirip cluster yang dihasilkan sistem dengan yang ditentukan ahli.

Berdasarkan pengujian clusteryang ditunjukkan pada Tabel 2. dapat diambil kesimpulan sebagai berikut:

1. Dari 30 data uji, hanya satu yang semua klasterisasi datanya sama persis dengan ahli, yaitu trending topic "WorldCancerDay".

2. Ada 1 data uji pada trending topic "Berhenti Langganan IndiHome" semua klasterisasinya sangat tidak mirip atau jauh berbeda dengan yang ditentukan ahli.

3. Ada 2 data uji, yaitu trending topic "Chris Martin" dan "HitzSirkusPagi" memperoleh satu klaterisasi data yang sama persis dengan yang ditentukan ahli (terdiri atas 2-9 cluster untuk setiap trending topic).

4. Sisa data uji 26 trendingtopic, rata-rata semuanya hanya mendapatkan satu klasterisasi yang hampir mirip dengan yang ditentukan ahli (terdiri atas 2-9 cluster untuk setiap trending topic).

5. Data cluster atau sub tema yang mirip dengan ahli dihasilkan saat terdapat banyak data retweet pada suatu trending topic.

Contohnya pada pengujian ini terdapat nilai F-Measure 100\% semua untuk setiap cluster atau sub tema pada trending topic "WorldCancerDay", artinya semua hasil cluster yang dihasilkan oleh sistem dengan yang dihasilkan oleh ahli sama persis. Hasil tersebut bisa didapatkan karena, pada trending topic "WorldCancerDay" hanya terdapat 2 tweet yang berbeda, seperti yang ditunjukan pada Tabel 3. 
Tabel 2. F-Measure Persen

\begin{tabular}{|c|c|c|c|c|c|c|c|c|c|c|}
\hline \multirow[b]{2}{*}{ Trending Topic } & \multirow{2}{*}{$\begin{array}{l}\text { Jlh } \\
\text { Cluster }\end{array}$} & \multicolumn{9}{|c|}{ F-Measure } \\
\hline & & $\begin{array}{c}\text { Cluster } \\
1\end{array}$ & $\begin{array}{c}\text { Cluster } \\
2\end{array}$ & $\begin{array}{c}\text { Cluster } \\
3\end{array}$ & $\begin{array}{c}\text { Cluster } \\
4\end{array}$ & $\begin{array}{c}\text { Cluster } \\
5\end{array}$ & $\begin{array}{c}\text { Cluster } \\
6 \\
\end{array}$ & $\begin{array}{c}\text { Cluster } \\
7\end{array}$ & $\begin{array}{c}\text { Cluster } \\
8\end{array}$ & $\begin{array}{c}\text { Cluster } \\
9\end{array}$ \\
\hline 1 BSM Tabungan Berencana & 2 & $6 \%$ & $56 \%$ & & & & & & & \\
\hline 2 WorldCancerDay & 2 & $100 \%$ & $100 \%$ & & & & & & & \\
\hline 3 Ciledug & 2 & $6 \%$ & $56 \%$ & & & & & & & \\
\hline 4 dahSyatKamisKustik & 2 & $5 \%$ & $31 \%$ & & & & & & & \\
\hline 5 Fatwa MUI & 3 & $0 \%$ & $0 \%$ & $68 \%$ & & & & & & \\
\hline 6 HappyKyuDay & 3 & $0 \%$ & $0 \%$ & $72 \%$ & & & & & & \\
\hline 7 Niall is in Bali & 3 & $0 \%$ & $0 \%$ & $89 \%$ & & & & & & \\
\hline 8 Ahmadiyah & 4 & $13 \%$ & $10 \%$ & $0 \%$ & $35 \%$ & & & & & \\
\hline $\begin{array}{l}9 \text { ANAKJALANANSPESIAL } \\
\text { PART } 3\end{array}$ & 4 & $0 \%$ & $18 \%$ & $0 \%$ & $60 \%$ & & & & & \\
\hline 10 AskDokArt & 4 & $0 \%$ & $13 \%$ & $0 \%$ & $73 \%$ & & & & & \\
\hline 11 HTM $10 k$ & 4 & $0 \%$ & $0 \%$ & $29 \%$ & $69 \%$ & & & & & \\
\hline 12 Luais Suarez & 4 & $20 \%$ & $0 \%$ & $18 \%$ & $62 \%$ & & & & & \\
\hline 13 NOTRECOM & 4 & $0 \%$ & $0 \%$ & $0 \%$ & $63 \%$ & & & & & \\
\hline $\begin{array}{l}\text { DOAQU BUAT SINGLE } \\
\text { IRWANDA2 }\end{array}$ & 4 & $67 \%$ & $15 \%$ & $15 \%$ & $68 \%$ & & & & & \\
\hline 15 BreakoutNET_Band & 4 & $33 \%$ & $0 \%$ & $13 \%$ & $65 \%$ & & & & & \\
\hline 16 BestCutOfPiyuDiPro2FM & 4 & $15 \%$ & $0 \%$ & $42 \%$ & $0 \%$ & & & & & \\
\hline 17 Chris Martin & 5 & $100 \%$ & $15 \%$ & $0 \%$ & $0 \%$ & $54 \%$ & & & & \\
\hline 182.500 Pekerja Kena PHK & 5 & $11 \%$ & $0 \%$ & $50 \%$ & $0 \%$ & $61 \%$ & & & & \\
\hline 19 7ManusiaHariamueps569 & 5 & $40 \%$ & $0 \%$ & $0 \%$ & $0 \%$ & $72 \%$ & & & & \\
\hline 20 AdaSHanisaJKT48LagiDiTMG & 5 & $0 \%$ & $33 \%$ & $10 \%$ & $0 \%$ & $55 \%$ & & & & \\
\hline 21 BANG IPULDA3 IVM & 5 & $33 \%$ & $0 \%$ & $0 \%$ & $0 \%$ & $56 \%$ & & & & \\
\hline 22 BELAHANJIWAKAHRAMAN55 & & $14 \%$ & $0 \%$ & $0 \%$ & $0 \%$ & $64 \%$ & & & & \\
\hline 23 70tahunPMI & 6 & $0 \%$ & $17 \%$ & $40 \%$ & $0 \%$ & $0 \%$ & $70 \%$ & & & \\
\hline 24 DaruratLGBT & 6 & $20 \%$ & $0 \%$ & $0 \%$ & $0 \%$ & $0 \%$ & $58 \%$ & & & \\
\hline 25 AkhimyaRAISAkeIniTalkShow & 7 & $40 \%$ & $25 \%$ & $22 \%$ & $0 \%$ & $0 \%$ & $0 \%$ & $60 \%$ & & \\
\hline 26 Bintang & 7 & $25 \%$ & $40 \%$ & $17 \%$ & $0 \%$ & $29 \%$ & $0 \%$ & $34 \%$ & & \\
\hline 27 HitzSirkusPagi & 7 & $100 \%$ & $18 \%$ & $0 \%$ & $0 \%$ & $0 \%$ & $0 \%$ & $70 \%$ & & \\
\hline 28 Kick Andy & 7 & $0 \%$ & $0 \%$ & $17 \%$ & $0 \%$ & $36 \%$ & $20 \%$ & $0 \%$ & & \\
\hline 29 Berhenti Langganan IndiHome & 8 & $40 \%$ & $0 \%$ & $33 \%$ & $33 \%$ & $0 \%$ & $0 \%$ & $0 \%$ & $44 \%$ & \\
\hline 30 Gemini & 9 & $20 \%$ & $0 \%$ & $67 \%$ & $0 \%$ & $0 \%$ & $67 \%$ & $0 \%$ & $0 \%$ & $43 \%$ \\
\hline
\end{tabular}

\section{Keterangan:}

= sama persis (semua komposisi anggota cluster sama)

= hampir mirip(lebih dari setengah komposisi anggota cluster sama)

Kedua, pengujian ringkasan menggunakan metode intrinsik ROUGE- $N[6,7]$. Pengukuran ROUGE-N mengukur perbandingan $\mathrm{N}$-gram dari dua ringkasan, dan menghitung berapa jumlah yang sesuai, dirumuskan dalam Persamaan 7:

Tabel 3. Retweet

\begin{tabular}{|c|c|}
\hline Data Tweet & Tweet \\
\hline 1 & $\begin{array}{l}\text { Ketahui penyebabnya, kenali gejalanya, lawan dan jangan pernah } \\
\text { menyerah pada penyakitnya \#WeCanICan \#WorldCancerDay } \\
\text { https://t.co/9XpM3QRc1S" }\end{array}$ \\
\hline $2-50$ & $\begin{array}{l}\text { RT @ arif_yusa: Selamat Hari Kanker Sedunia! Bersama-sama, mari kita } \\
\text { ngopi... menurut penelitian minum kopi hitam dapat mencegah kanker. \# } \\
\text { WorldCancerDay }\end{array}$ \\
\hline
\end{tabular}




$$
R O U G E-N=\frac{\sum_{S} \in \operatorname{summ}_{\text {ref }} \sum N-\text { gramm }_{s} \operatorname{count}_{\text {match }}(N-\text { gram })}{\sum_{S} \in \text { summ }_{\text {ref }} \sum N-\text { gramm }_{s} \operatorname{count}(N-\text { gram })}
$$

Pada Persamaan 8, notasi $\mathrm{N}$ menunjukkan panjang dari $\mathrm{N}$-gram, Count match $(\mathrm{N}$-gram) adalah jumlah maksimum dari $\mathrm{N}$-gram yang muncul pada ringkasan kandidat dan ringkasan sebagai referensi. Count( $\mathrm{N}$-gram) adalah jumlah dari $\mathrm{N}$-gram pada ringkasan sebagai referensi.

Skenario pengujian ringkasan tweet pada penelitian ini adalah dengan membandingkan hasil ringkasan manual yang dibuat oleh ahli dengan hasil ringkasan yang dihasilkan oleh sistem.Pertama ahli melakukan klasterisasi data tweet suatu trending topic secara manual dengan jumlah cluster yang telah ditentukan terlebih dahulu. Kemudian berdasarkan cluster yang terbentuk tadi, ahli memilih salah satu tweet dalam setiap cluster untuk mewakili anggotanya yang lain, tweet yang dipilih untuk mewakili cluster tersebutlah yang dijadikan pembanding antara kesimpulan yang dihasilkan oleh sistem dengan kesimpulan yang ditentukan oleh ahli.

Pada penelitian ini fungsi $R O U G E-N$ yang digunakan adalah $R O U G E$ dengan nilai $\mathrm{N}=1$. ROUGE dengan nilai $\mathrm{N}=1$ berarti membandingkan kesamaan hasil ringkasan dengan ringkasan referensi untuk setiap satu kata. Sebelum dilakukan pengukuran dengan ROUGE-1, hasil ringkasan tweet dilakukan preproses data terlebih dahulu, yang terdiri atas tahapan case folding, tokenizing, editing, menghilangkan stopwords, normalisasi, dan stemming. berikut:

Berdasarkan hasil pengujian ringkasan pada Tabel 5. dapat diambil kesimpulan sebagai

1. Dari 30 data uji, hanya satu yang semua kesimpulan untuk setiap sub tema sama persis dengan ahli, yaitu trending topic "WorldCancerDay".

2. Selain data uji trending topic "WorldCancerDay", sisa 29 data uji rata-rata menghasilkan 1-4 kesimpulan yang sama persis dengan ahli (terdiri atas 2-9 kesimpulan untuk setiap trending topic).

3. Diambil contoh salah satu data trending topic dari pengujian dengan nilai ROUGE-1 paling kecil (memperoleh nilai 0), yaitu data dengan trending topic "dahSyatkamisKustik". Hal tersebut bisa terjadi karena, ringkasan yang dihasilkan oleh sistem dengan yang ditentukan ahli memang berbeda jauh dari segi padanan kata dan artinya, seperti ditunjukan pada Tabel 4. sebagai berikut:

Tabel 4. Beda Ringkasan

\begin{tabular}{ll}
\hline \multicolumn{1}{c}{ Ahli } & \multicolumn{1}{c}{ Ringkasan } \\
\hline \begin{tabular}{l}
\multicolumn{1}{c}{ ST @Mustem } \\
lagi nonton @GEISHAdios: Jangan lupa nih yang \\
\#dahsyatKamisKustik download lagunya di \\
https://t.co/TAyig81SKG
\end{tabular} & $\begin{array}{l}\text { \#dahSyatKamisKustik Kalau kaum pria } \\
\text { berkumpul, mereka saling mendengarkan, } \\
\text { sedangkan kalau kaum wanita berkumpul, } \\
\text { mereka saling mengamati. }\end{array}$ \\
\hline
\end{tabular}

\section{Kesimpulan}

Berdasarkan sistem yang telah dibuat dan pengujian yang telah dilakukan, dapat diambil dua kesimpulan, yaitu pertama cluster yang baik atau bagus terbentuk dari trending topic yang banyak mengandung data retweet. Dari 30 data uji ada 3 data trending topic dengan hasil salah satu F-Measurecluster-nya mencapai 100\% berdasarkan Tabel 2. (hasil cluster keluaran sistem sama persis dengan cluster yang ditentukan ahli), yaitu trending topic "WordCancerDay", "Chris Martin" dan "HitzSirkusPagi".

Kedua, perbedaan antara komposisi anggota cluster dari sistem dengan komposisi anggota cluster dari ahli, masih memungkinkan pemilihan tweet yang sama sebagai ringkasan. Hal tersebut dipengaruhi oleh subjektifitas ahli dalam menentukan ringkasan.

Beberapa saran yang dapat dilakukan untuk pengembangan sistem ini, yaitu pertama menambahkan algoritma yang dapat memilih level cluster terbaik dan lebih efektif selain dengan UPGMA(Unweighted Pair Group Method Average). Kedua, menambahkan algortima yang dapat menghasilkan ringkasan tweet dengan teknik abstraktif, yaitu menghasilkan ringkasan dengan kalimat-kalimat baru yang mewakili intisari dari setiap anggota cluster atau 
sub tema. Ketiga, menambahkan preprocessing untuk tahapan editing, normalisasi, dan stemming dalam sistem, karena pada penelitian ini ketiga tahapan tersebut dilakukan secara manual.

Tabel 5. ROUGE-1

\begin{tabular}{|c|c|c|c|c|c|c|c|c|c|c|c|}
\hline \multirow{2}{*}{ No } & \multirow{2}{*}{ Trending Topic } & \multirow{2}{*}{$\begin{array}{c}\text { Jh } \\
\text { Cluster }\end{array}$} & \multicolumn{9}{|c|}{ F-Measure } \\
\hline & & & $\begin{array}{c}\text { Cluster } \\
1 \\
\end{array}$ & $\begin{array}{c}\text { Cluster } \\
2 \\
\end{array}$ & $\begin{array}{c}\text { Cluster } \\
3\end{array}$ & $\begin{array}{c}\text { Cluster } \\
4\end{array}$ & $\begin{array}{c}\text { Cluster } \\
5 \\
\end{array}$ & $\begin{array}{c}\text { Cluster } \\
6 \\
\end{array}$ & $\begin{array}{c}\text { Cluster } \\
7 \\
\end{array}$ & $\begin{array}{c}\text { Cluster } \\
8 \\
\end{array}$ & $\begin{array}{c}\text { Cluster } \\
9 \\
\end{array}$ \\
\hline 11 & BSM Tabungan Berencana & 2 & 0,333 & 1,000 & & & & & & & \\
\hline$\overline{2}$ & WorldCancerDay & 2 & 1,000 & 1,000 & & & & & & & \\
\hline 3 & Ciledug & 2 & 1,000 & 0,056 & & & & & & & \\
\hline $4 \mathrm{c}$ & dahSyatKamisKustik & 2 & 0,000 & 1,000 & & & & & & & \\
\hline$\overline{51}$ & Fatwa MUI & 3 & 0,214 & 0,190 & 0,400 & & & & & & \\
\hline$\overline{61}$ & HappyKyuDay & 3 & 0,211 & 0,000 & 1,000 & & & & & & \\
\hline $7 \quad 1$ & Niall is in Bali & 3 & 0,235 & 0,276 & 1,000 & & & & & & \\
\hline 8 & Ahmadiyah & 4 & 0,067 & 0,057 & 0,067 & 0,333 & & & & & \\
\hline & $\begin{array}{l}\text { ANAKJALANANSPESIAL } \\
\text { PART } 3\end{array}$ & 4 & 0,400 & 0,276 & 0,296 & 1,000 & & & & & \\
\hline & AskDokArt & 4 & 0,100 & 0,091 & 0,000 & 0,000 & & & & & \\
\hline 111 & HTM $10 \mathrm{k}$ & 4 & 0,182 & 1,000 & 0,167 & 1,000 & & & & & \\
\hline 121 & Luais Suarez & 4 & 0,173 & 0,182 & 1,000 & 1,000 & & & & & \\
\hline $13 \mathrm{I}$ & NOTRECOM & 4 & 0,183 & 0,118 & 0,125 & 1,000 & & & & & \\
\hline & $\begin{array}{l}\text { DOAQU BUAT SINGLE } \\
\text { IRWANDA2 }\end{array}$ & 4 & 0,588 & 1,000 & 0,556 & 1,000 & & & & & \\
\hline 151 & BreakoutNET_Band & 4 & 0,000 & 0,000 & 0,000 & 0,463 & & & & & \\
\hline 161 & BestCutOfPiyuDiPro2FM & 4 & 0,000 & 0,000 & 0,333 & 0,061 & & & & & \\
\hline 17 & Chris Martin & 5 & 1,000 & 0,286 & 0,000 & 0,200 & 1,000 & & & & \\
\hline 182 & 2.500 Pekerja Kena PHK & 5 & 0,071 & 0,267 & 0,273 & 0,214 & 1,000 & & & & \\
\hline 197 & 7ManusiaHariamueps569 & 5 & 0,000 & 0,087 & 0,069 & 0,000 & 0,000 & & & & \\
\hline 20 & AdaSHanisaJKT48LagiDiTMG & 5 & 0,000 & 0,000 & 0,000 & 0,000 & 1,000 & & & & \\
\hline 211 & BANG IPUL DA3 IVM & 5 & 1,000 & 0,000 & 0,387 & 0,400 & 1,000 & & & & \\
\hline 221 & BELAHANJIWAKAHRAMAN55 & 55 & 0,000 & 0,000 & 0,000 & 0,000 & 0,083 & & & & \\
\hline 237 & 70tahunPMI & 6 & 0,000 & 0,000 & 0,167 & 0,286 & 0,000 & 0,667 & & & \\
\hline $24 \mathrm{I}$ & DaruratLGBT & 6 & 0,182 & 0,364 & 0,345 & 0,143 & 0,174 & 1,000 & & & \\
\hline 25 & AkhirnyaRAISAkeIniTalkShow & 7 & 0,083 & 0,000 & 0,125 & 1,000 & 1,000 & 0,105 & 1,000 & & \\
\hline 261 & Bintang & 7 & 1,000 & 1,000 & 0,000 & 0,087 & 0,182 & 0,083 & 0,400 & & \\
\hline 271 & HitzSirkusPagi & 7 & 1,000 & 0,250 & 0,000 & 0,000 & 0,000 & 0,000 & 1,000 & & \\
\hline 281 & Kick Andy & 7 & 0,191 & 0,194 & 0,133 & 0,462 & 1,000 & 1,000 & 0,250 & & \\
\hline 291 & Berhenti Langganan IndiHome & 8 & 1,000 & 0,348 & 0,353 & 1,000 & 1,000 & 0,348 & 0,361 & 1,000 & \\
\hline & Gemini & 9 & 0,261 & 0,207 & 0,083 & 0,111 & 0,000 & 0,077 & 0,125 & 0,111 & 1,000 \\
\hline
\end{tabular}

Keterangan:

= sama persis(ringkasan sistem dengan ahli sama persis)

\section{Refrensi}

[1] Erkan, Günes, dan Dragomir R. Radev. "LexRank: Graph-based lexical centrality as salience in text summarization." Journal of Artificial Intelligence Research (2004): 457479.

[2] Móro, Róbert, dan M. Bielikov. "Personalized text summarization based on important terms identification." Database and Expert Systems Applications (DEXA), 2012 23rd International Workshop on. IEEE, 2012.

[3] Berkhin, Pavel. "A survey of clustering data mining techniques." Grouping multi dimensional data. Springer Berlin Heidelberg, 2006. 25-71.

[4] Hamzah, Amir, F.Soesianto, dan Jazi Eko Istiyanto . "Studi Kinerja Fungsi-Fungsi Jarak dan Similaritas dalam Clustering Dokumen Teks Berbahasa Indonesia." Seminar Nasional Informatika (SEMNASIF). Vol. 1. No. 1. 2015.

[5] Steinbach, Michael, George Karypis, dan Vipin Kumar. "A comparison of document clustering techniques." KDD workshop on text mining. Vol. 400. No. 1. 2000.

[6] LIN, C.Y. 2004. ROUGE: A Package for Automatic Evaluation of Summaries. Proceedings of Workshop on Text Summarization Brances Out.

[7] Santika, Putu Praba, and Gus Nanang Syaifuddin. "Semantic Clustering Dan Pemilihan Kalimat Representatif Untuk Peringkasan Multi Dokumen." Jurnal Teknologi Informasi dan IImu Komputer 1.2 (2015). 